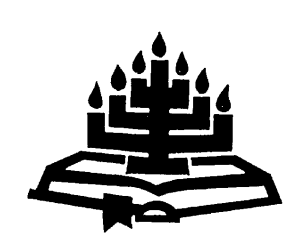

\title{
Die menswaardigheid van die menslike embrio: die debat tot dusver
}

\author{
J.M. Vorster \\ Eenheid vir Reformatoriese Teologie \\ Potchefstroomkampus \\ Noordwes-Universiteit \\ POTCHEFSTROOM \\ E-pos: koos.vorster@nwu.ac.za
}

\section{Abstract}

The human dignity of the human embryo: the debate thus far

This article examines some recent arguments regarding the ethics of stem cell research as they are discussed in the various essays in the publication of Gruen et al. (2007), "Stem cell research: the ethical issues". Regarding the use of human embryos in stem cell research, these essays discuss among other things the potential of the human embryo, the moral status (human dignity) of the human embryo, the creation of chimeras, the sale of ocytes and other ethical issues in modern bioethics. Eventually the article draws attention to the main ethical problems at stake to be dealt with by Christian ethics using a deontological ethical theory. Christian ethics should focus on these problems in the on-going ethical debate regarding stem cell research.

\section{Opsomming}

Die menswaardigheid van die menslike embrio: die debat tot dusver

Hierdie artikel fokus op sommige onlangse argumente in verband met die etiek van stamselnavorsing soos dit beredeneer word in die artikels in die publikasie van Gruen et al. (2007), "Stem cell research: the ethical issues". Rakende die gebruik van menslike embrio's in stamselnavorsing, behandel hierdie artikels die potensiaal van die menslike embrio, die morele status (menswaardigheid) van die embrio, die skepping van chimeras, die verkoop van oösiete en ander etiese kwessies in die moderne bioetiek. Ten slotte wys die artikel op die belangrikste etiese sake waaraan 'n Christelike etiek, uitgaande van 'n 
deontologiese etiese teorie, aandag behoort te gee om 'n bydrae tot die kontemporêre bio-etiese debat te lewer.

\section{Inleiding}

Op 9 Maart 2009 het die nuwe president van die Verenigde State, President Barack Obama, die agt jaar oue verbod op federale befondsing vir embrioniese stamselnavorsing in die VSA opgehef (Lite, 2009:1). Die verbod is op 9 Augustus 2001 deur sy voorganger, President George Bush (2001:1), om etiese redes ingestel na 'n lang debat oor die saak sedert die sewentigerjare van die vorige eeu (vgl. Campbell, 2005:54). Bush se hoofrede was dat die menslike embrio 'n "organisme" is wat in staat is om 'n mens te word wanneer dit in die uterus ingeplant word (Gruen \& Grabel, 2007:2). Embrioniese stamselnavorsing bring die vernietiging van menslike embrio's mee en is dus, volgens die Bush-kompromis, oneties. Obama, daarenteen, het sy opheffing van die verbod 'n belangrike stap in die vordering van die wetenskap in Amerika genoem en gesê:

In recent years, when it comes to stem cell research, rather than furthering discovery, our government has forced what I believe is a false choice between sound science and moral values. In this case I believe the two are not inconsistent. As a person of faith, I believe we are called to care for each other and work to ease human suffering. I believe we have been given the capacity and will to pursue this research - and the humanity and conscience to do so responsibly. (Obama, 2009:1.)

Voorstanders van embrioniese stamselnavorsing is oortuig dat hierdie navorsing eendag sal bydra tot die effektiewe behandeling van siektes soos Parkinson en Altzheimer se siektes, hartsiektes, diabetes, osteoarteritis, gesigs- en gehoorverlies, Duchen se spierdistrofie, en om rugbeserings te herstel (vgl. Campbell, 2005:49; Kalb, 2009:2; Rheeder, 2008a:495). Ouers kan byvoorbeeld ook 'n kind in die wêreld bring met die doel om die kind se selle oor te plant ten einde hulle ander siek kind te genees (Robertson et al., 2002:34). Obama se opheffing van die verbod op die federale befondsing vir embrionale stamselnavorsing was 'n historiese gebeurtenis, want dit het die etiek van stamselnavorsing in geheel weer in die kollig geplaas. ${ }^{1}$ In die verskillende tradisies in die Christelike etiek is hierdie

1 Die sienings in hierdie verband, soos dit in verskeie vooraanstaande mediese navorsingslande in wetgewing vervat is, wissel van 'n beperking op die skep van menslike embrio's vir navorsing tot 'n oop benadering waar sodanige skepping van embrio's vir navorsing toegelaat word. Baie lande verkies 'n 
saak ook aktueel (vgl. Childress, 2001:261; Cave, 2004:13; en Rheeder, 2008a:472). In die etiese diskoers word veral gefokus op die vraag of menslike embrio's gekweek kan word om in stamselnavorsing gebruik te word, veral vanweë die feit dat dit die vernietiging van embrio's teweegbring. Hieroor het Rheeder (2008b:711) onlangs in ' $n$ insiggewende artikel in In die Skriflig besin en 'n waardevolle etiese argument aan die orde gestel.

Die debat handel veral oor die produksie van embrio's vir die doel van navorsing (Campbell, 2005:51). In die besonder word gevra: Wat is die morele status (menswaardigheid) van die embrio? (Holm, 2002:497). ${ }^{2}$ Kan 'n embrio beskou word as menswaardig op grond waarvan etici kan oordeel dat die embrio die reg op lewe het? ${ }^{3}$ Het die fetus die reg op grondwetlike beskerming kragtens die fundamentele reg op lewe? Hierdie vrae is steeds prominent in die debat oor die etiek van stamselnavorsing (vgl. Iohannes Paulus, 1995; Robinson, 2002:33; Holm, 2002:493; Chu, 2003:530; Oderberg, 2005: 21; en Campbell, 2005:48).

Hierdie navorsing wil 'n voorlopige perspektief bied op die menswaardigheid van die menslike embrio. Om die doel te bereik word twee argumentasielyne aan die orde gestel. Die eerste argumentasielyn gee 'n oorsig oor die etiese debat oor hierdie saak soos ver-

kompromisposisie wat wel onder sekere omstandighede sodanige navorsing toelaat, maar onder streng regulasies. Die drie benaderingswyses word getipeer deur die wetgewing in onderskeidelik Duitsland, die VSA en Japan. In haar ondersoek toon Campbell (2005:64) aan dat Duitsland stamselnavorsing oor die algemeen verbied, dat die VSA 'n kompromisposisie handhaaf en dat Japan baie vryheid aan navorsers in hierdie verband toelaat. Die Konrad Adenhauer Stiftung het 'n publikasie die lig laat sien wat die Duitse standpunt goed uiteensit (vgl. Vogel, 2007). Hierdie verskil in benaderings het gelei tot die migrasie van navorsers en 'n grondige belangstelling in die etiek van stamselnavorsing.

$2 \quad$ In die filosofiese etiek en in die bio-etiek word die term morele status in plaas van "menswaardigheid" gebruik. In hierdie artikel word die terme egter as sinonieme gebruik. In die bespreking van die onderskeie skrywers se standpunte word hulle term morele status gebruik, maar daaronder word dieselfde bedoel as die menswaardigheid waarin in die titel en die fokus van hierdie navorsing verwys word.

$3 \quad$ Hierdie vraag was ook onder bespreking toe aborsie op aanvraag 'n etiese kwessie geword het, maar in daardie gesprekke het dit nie soseer oor die embrio gegaan nie, maar oor die fetus tot en met die ouderdom van veertien weke. Baie van die argumente is egter ook geldig in die debat oor embrionale stamselnavorsing. In hierdie verband kan verwys word na die sienings wat Gustafson (1981:101) huldig. 
woord in die onlangse werk van Gruen et al. (2007). Die tweede deel, waaroor in 'n volgende artikel gehandel sal word, poog om die vraag oor die morele status van die menslike embrio voorlopig te hanteer vanuit 'n Christelike etiese hoek en 'n deontologiese etiese teorie, asook die teorieë toepaslik op die hantering van morele konflikte (vgl. Vorster, 2004:105). Die argumentasielyn van hierdie artikel word gebou op grond van die werk van Gruen et al. (2007), omdat hierdie bundel ' $n$ besondere oorsig gee van die vernaamste kontemporêre bio-etiese standpunte oor stamselnavorsing. Die standpunte van die skrywers in hierdie bundel word dus ontleed ten einde vas te stel in hoe verre hulle perspektiewe bied waaroor die Christelike etiek sal moet besin.

\section{Onduidelikheid oor die status van die embrio - Devolder en Harris}

Devolder en Harris (2007:16) begin hulle artikel met die stelling: "The embryo is a deeply, perhaps irretrievably ambiguous entity, one that defies classification and slips seamlessly between moral and biological categories." Hulle voer vir hierdie stelling verskeie redes aan. Splitsing van embrio's kan gedoen word in verskeie stadia van embrioniese ontwikkeling. Die verdeelde embrio kan in die uterus ingeplant word en as 'n tweeling ontwikkel, of een van die twee kan vernietig word en die ander een kan ontwikkel. Die embrio kan ook in vier of meer embrio's verdeel word en later weer saamgevoeg word tot een embrio. Hierdeur word die situasie geskep waar 'n enkele sel, sonder om vernietig te word, weer saamgevoeg kan word. Wanneer drie van die vier egter vernietig word, is die mediese navorser weer terug by die beginpunt, naamlik een embrio. Uit een embrio kan ander embrio's geskep word vir navorsingsdoeleindes, sonder dat die oorspronklike embrio vernietig hoef te word. Hulle vra dan die vraag "Did 'life' in such a case begin as an individual, become four individuals and then turn into a single embryo again?" (Devolder \& Harris, 2007:17). As gevolg van hierdie gegewens maan die navorsers tot versigtigheid wanneer beweer word dat konsepsie die beginpunt van menslike lewe is en dat die embrio 'n individuele persoon in wording is. Hierdie siening is in 2005 reeds deur Oderberg (2005:23) bevraagteken. Verdeling van 'n embrio beteken vir hom dat uit die een individuele organisme meerdere individuele organismes ontstaan wat dieselfde morele status het as die een waaruit dit ontstaan het. Elke embrio, hoe dit ook al ontstaan, het 'n individualiteit en as sodanig 'n morele status. 
Verder bespreek Devolder en Harris (2007:18) die argument dat die embrio "potensieel" mens is en dus 'n bepaalde morele status (of menswaardigheid) besit (vgl. Pope, 2007:188; Brown, 2007:615; Oderberg, 2005:31). Hulle sien twee probleme in hierdie argument: Eerstens, beteken die feit dat iets die potensiaal het om iets anders te word, nie dat dit hanteer moet word asof dit die potensiaal alreeds bereik het nie. As voorbeeld wys hulle daarop dat mense potensieel dood is omdat almal sterflik is. Dit beteken egter nie dat mense nou soos dooies hanteer moet word nie (Devolder \& Harris, 2007:19). Elke ontwikkelingstadium moet binne 'n eie raamwerk hanteer word en daarom moet die embrio as embrio en die mens as mens hanteer word.

Die tweede argument handel oor die standpunt dat die embrio se potensiële menswees die reikwydte van die potensiaal van menswees in die gesigsveld bring. Indien die menslike sigoot die potensiaal het om 'n volwasse mens te word, wat dan van die potensiaal van gamete of selle om 'n sigoot te word? Die onbevrugte eiersel en die sperm het die potensiaal om 'n sigoot te word en het dus as sodanig die potensiaal om volledig mens te word. Dit is moontlik om eierselle te stimuleer om te verdeel en te ontwikkel sonder bevrugting. Hierdie tegniek is gebruik in die kloning van Dollie, die eerste gekloonde skaap (Devolder \& Harris, 2007:20). Hoewel hierdie tegniek by mense nog nie ver ontwikkel is nie, sou dit beteken dat indien dit moontlik is, die onbevrugte eiersel sonder sperm of as gevolg van kloning die potensiaal van 'n sigoot het, wat weer die potensiaal het om ' $n$ volwasse mens te word. As potensialiteit gebruik word om aan die embrio morele status toe te ken, moet dieselfde status ook aan die eiersel of enige menslike sel toegeken word. Op grond hiervan oordeel hulle dat die argument oor die potensialiteit van die menslike embrio as grond vir die toekenning van morele status (menswaardigheid) aan die embrio problematies is.

Devolder en Harris (2007:23) bevraagteken ook die stelling dat 'n embrio en fetus enige regte kan hê. Met verwysing na die navorsing van Cohen et al., onderskei hulle tussen twee teorieë wanneer regte ter sprake kom, naamlik "keuseteorie" en "belangeteorie". Keuseteorie ten opsigte van menseregte impliseer dat regte moet dien vir die beskerming en bevordering van outonomie en vryheid van die individu. Hierdie teorie kan, volgens hulle, egter nie op die embrio van toepassing wees nie, omdat die embrio nie in staat is om keuses te maak nie. Die "belangeteorie" impliseer dat regte moet dien vir die individuele welsyn. Hierdie teorie kan eweneens nie op die embrio 
van toepassing gemaak word nie, omdat die embrio weens die gebrek aan 'n sentrale senuweestelsel en 'n brein nie welsyn kan ervaar nie. Die embrio het dus geen regte in die menseregte sin van die woord nie. Hulle wys ook daarop dat die internasionale reg en die meeste regstelsels geen regte aan die embrio of fetus toeken nie.

As verdere ondersteunende argument vir hulle beskouing dat die embrio nie morele status kan hê nie, verwys Devolder en Harris (2007:24) na die feit dat baie embrio's in elk geval verlore gaan in normale menslike reproduksie. Hulle is oortuig dat hierdie feite aantoon dat die teenstanders van die gebruik van embrio's in stamselnavorsing 'n ambivalente benadering oor die morele status van die embrio vertoon. In hierdie opsig verwys hulle na die navorsing van Boklage en Leridan wat aangetoon het dat daar vir elke geboorte drie embrio's verlore gaan en dat twee-derdes tot driekwart van alle embrio's nie inplant nie. Baie embrio's gaan ook verlore as gevolg van verskillende geboortebeperkingsmiddels wat mense toepas, waar inplanting van embrio's deur kontrasepsie verhoed word. Vernietiging van embrio's vind dus op 'n wye vlak plaas as die neweeffek van menslike seksualiteit. Dit is, volgens hulle, veral belangrik om daarop te let dat hierdie embrio's vernietig word op dieselfde ouderdom, te wete vyf tot agt dae, as wat embrio's vir stamselnavorsing geoes word. Devolder en Harris (2007:26) kom tot die konklusie: "We, humankind, must accept that human embryos are deeply ambiguous and problematic entities of a kind whose lives or 'dignity' simply cannot be protected in ways consistent with other values we hold." Hulle pleit vir die gebruik van embrio's in stamselnavorsing omdat die gesindheid waarmee dit gedoen word nie destruktief is nie, maar voordeel vir die mens inhou omdat dit ernstige siektes kan genees.

\section{Die vernietiging van embrio's vir stamselnavorsing - MacMahan}

MacMahan (2007:32) verwoord in sy standpunt die siening van verskeie bio-etici dat die embrio geen morele status kan hê nie. In hierdie verband kan verwys word na Stretton (2000:239) en Gibson (2007:372). Hy beroep hom in sy beredenering oor die morele status van die menslike embrio eerstens op die wetenskaplike getuienis in 2006 dat stamselle uit embrio's gekweek kan word sonder dat die oorspronklike embrio's vernietig hoef te word. Op die oomblik is hierdie stelling egter net teoreties waar, want in stamselnavorsing word die geproduseerde embrio's tog wel vernietig, net soos die geval is 
met embrio's wat gekweek word vir in vitrobevrugting. Hy gee wel erkenning aan hierdie feit. Hy noem twee aannames wat etici gebruik in hulle afwysing van die gebruik van embrio's vir stamselnavorsing, naamlik:

- Die embrio is die vroegste stadium in die menslike bestaan - alle mense was eers embrio's.

- Mense het dieselfde morele status te alle tye van hulle bestaan. Mense het dus dieselfde morele status as embrio's as later in hulle lewens.

Hy wys daarop dat hierdie aannames oor die beweerde morele status van die embrio's nie net religieus georiënteer is nie, maar dat hierdie siening van die embrio ook in die sekulêre gemeenskap figureer. Daar word beweer dat die embrio's menslik is en as sodanig 'n morele status behoort te geniet (MacMahan, 2007:33). Tog is die argument nie vir hom oortuigend nie, omdat die embrio vyf of ses dae na konsepsie reeds gereed is vir selkweking. Op hierdie stadium het die embrio in normale omstandighede in elk geval slegs 'n $30 \%$ kans op oorlewing.

Voorts vind verdeling van die embrio in die geval van die vorming van tweelinge eers veertien dae na konsepsie plaas. Dan eers begin die tweeling bestaan. Met verwysing na McCall-Smith oordeel hy dat die embrio minstens tot dan nie as menslik beskou kan word nie. Indien dit as menslik beskou word, moet monosigotiese verdeling (soos wat tweelinge gevorm word) verhinder word. Hy sê:

I accept the familiar idea that the living human organism is an entity with human genes that is composed of various living parts that function together in an integrated way to sustain a single life, and that is not itself a part of another living biological entity. (MacMahan, 2007:40.)

Die embrio voldoen nie hieraan nie en kan dus nie as menslik gesien word nie. Hy sê verder dat die argument oor die begin van lewe moet koördineer met die argument oor die einde van lewe. Lewe eindig wanneer die brein sterf, maar so 'n liggaam het veel meer selkoördinasie as die embrio. Hoe kan die embrio dan as mens beskou word? Hy baseer sy siening op die Kantiaanse siening dat mense is vanweë die feit dat hulle 'n rasionele kapasiteit het (vgl. Gibson, 2007:372). Hy verwys verder na die feit dat baie embrio's in die proses van in vitrobevrugting vernietig word. Dit blyk volgens hom eties meer korrek om die embrio vir 'n goeie doel aan te wend as om dit te laat sterf (MacMahan, 2007:36). Vanuit hierdie konsekwensia- 
listiese teorie bevind hy dat die gebruik en vernietiging van embrio's vir stamselnavorsing eties geoorloof is. Gibson (2007:370) gee ook voorkeur aan sodanige konsekwensialistiese benadering.

Die vraag of die embrio ' $n$ menslike organisme is, is vir MacMahan (2007:43) eintlik 'n metafisiese vraag wat 'n filosofiese antwoord verg. Hy poog om self so ' $n$ antwoord te gee en doen dit dan by wyse van hipotetiese argumente oor die moontlikheid van brein-oorplantings en skeiding van Siamese tweelinge en die invloed wat sulke handelings op die metafisiese beskouing van die morele status van die embrio kan hê. Hierop word nie in hierdie artikel verder ingegaan nie, omdat die argumente op hipoteses berus. Wat egter in sy beredenering belangrik is, is die vrae wat hy vra oor die standpunt in godsdienstige kringe dat die embrio vanaf konsepsie 'n siel het. MacMahan (2007:45) vra:

- Wat is die aard van die siel, aangesien 'n mens se psigologiese samestelling deur die brein bepaal en beheer word?

- Om watter rede kan veronderstel word dat die siel bestaan?

- Het diere ook 'n siel?

- In watter stadium van die evolusie van die mens het die siel ontstaan?

- Kan die siel sonder die liggaam voortbestaan as bewys word dat die mens se psigologiese eienskappe deur die brein beheer word?

Op grond van hierdie vrae kritiseer hy die Rooms-Katolieke siening dat die siel die "organiserende prinsipe" is wat aan die mens, anders as aan die dier, 'n rasionele kapasiteit gee. Hy meen dat die embrio geen siel kan hê nie, omdat dit nie 'n bewussyn het nie. Mense ontstaan eers wanneer hulle die kapasiteit kan ontwikkel om 'n bewussyn te hê en hou op bestaan wanneer die kapasiteit van 'n bewussyn tot niet is. Mense begin dus bestaan wanneer die fetale brein die kapasiteit van bewussyn ontwikkel, en dit gebeur binne 22 en 28 weke na konsepsie (MacMahan, 2007:48).

MacMahan (2007:48 \& 49) spreek hom ook uit oor die argumente dat die embrio potensieel mens is en 'n eie intrinsieke waarde het. $\mathrm{Hy}$ argumenteer dat die potensiaal van die embrio baie beperk is, net soos die individuele eier- en spermsel. Dit is slegs ' $n$ potensiaal wat die latere bestaan van 'n individu moontlik maak - 'n individu wat ver verwyder is van die embrio. Hy opper ook bedenkings oor 
die intrinsieke waarde van die embrio, veral in die lig van die feit dat twee-derdes van alle embrio's wat gevorm word voor inplanting sterf. Die embrio het nie veel meer intrinsieke waarde as die eiersel en die spermsel nie. In die lig van al hierdie argumente kom hy tot die slotsom dat dit nie moreel verkeerd is om 'n ses dag oue embrio dood te maak vir die doeleindes van navorsing nie (MacMahan, 2007:50). Hierdie argumente is oor die afgelope dekade deur baie bio-etiese navorsers aangebied ten gunste van die gebruik van embrio's vir stamselnavorsing (vgl. Stretton, 2000:228 en Schuklenk \& Lott, 2002:782).

\section{Die morele beginselbeswaar teen embrioniese stamselnavorsing - Marquis}

Marquis (2007:51) bespreek die argument van die morele beginselbeswaar teen embrioniese stamselnavorsing. Hy begin sy betoog deur te wys op die waarde van die gebruik van embrio's in stamselnavorsing. Hy definieer die embrio as die organisme wat bestaan vanaf die tyd van bevrugting tot met die tyd van inplanting. Die embrionale sel is die beste vir die gebruik in stamselnavorsing omdat dit ongedifferensieerd is en omdat dit vir veelvuldige stamselkweking gebruik kan word. Onder die morele beginselargument in die bioetiek verstaan hy die siening dat dit verkeerd is om 'n menslike lewe te beëindig ter wille van wetenskaplike navorsing, al sou die navorsing ook hoe belangrik en voordelig wees. Hierdie argument word, volgens hom, gebruik om te sê dat stamselnavorsing verkeerd is omdat dit beteken dat menslike lewens vernietig word ter wille van navorsing. Hy gee erkenning aan die feit dat hierdie argument nie net in godsdienstige kringe geopper word nie, maar ook in filosofiese en bio-etiese kringe (Marquis, 2007:52).

In sy hantering van hierdie argument begin hy met 'n erkenning dat die embrio menslike lewe is, want dit is 'n feit dat selle nie kan vermeerder indien hulle nie lewend is nie. Op hierdie punt verskil hy met MacMahan (Marquis, 2007:64) se Kantiaanse beskouing. Die embrio is dus menslike lewe. Hy aanvaar ook dat menslike lewe met bevrugting begin. Selfs die gevriesde embrio is lewend, want lewende selle word daaruit gekweek en die gevriesde embrio het nie onomkeerbare funksieverlies ondergaan soos by die sterwe van 'n mens nie. Verdedigers van die morele beginselbeswaar gebruik egter die terugverwysingstrategie (trace back strategy) om die standpunt te verdedig dat die embrio identies is aan die mens wat later daaruit ontwikkel. Hiervolgens word geargumenteer dat enige mens se geskiedenis teruggevoer kan word tot die tyd wat so 'n mens 'n 
sigoot was. Daarom is die embrio mens en kan dit nooit iets anders wees nie.

Maar tot waar kan hierdie argument gevoer word? In sy beantwoording van hierdie vraag verwys Marquis (2007:54) na verskeie bioetici wat elkeen 'n eie beginpunt vir menswees daar stel. Die standpunte loop wyd uiteen omdat die beginpunt van menslike lewe verskillend gesien word, byvoorbeeld by die begin van ' $n$ waarnemingsvermoë, wanneer 'n belang vir lewe getoon word, 'n begrip van selfidentiteit ontwikkel word, dit 'n persoon word of enige van die ander stadia van vroeë ontwikkeling.

Hy verwys ook na die standpunt van MacMahan wat inhou dat die embrio nie as 'n mens gesien kan word nie, omdat dit nie 'n rasionele organisme is nie. Net so min as wat mense nog mense is wanneer hulle rasionele kapasiteit verloor het, net so min kan die embrio 'n mens wees sonder ' $n$ rasionele komponent. Hierop is in die vorige afdeling gewys. MacMahan oordeel dat die vernietiging van die embrio as die mens se voorloper nie 'n vroeë fase van menswees beskadig nie. Al wat die vernietiging doen, is om ons bestaansmoontlikheid te verhoed soos tydens kontrasepsie. Marquis (2007: 64) wys hierdie siening af en is oortuig dat die embrio menslike lewe is. Dit is egter nie ' $n$ mens nie. Daarom is die "terugverwysingstrategie" as argument nie oortuigend nie.

Hy behandel ook die "toekoms-van-waarde"-argument wat ook in die morele beginselteorie gevoer word. Hierdie argument hou in dat dit immoreel is om die embrio te vernietig, omdat dit 'n toekoms van menswees het waarin die individu se waarde uitgeleef kan word. Die embrio is dus potensieel ' $n$ mens met waarde. Hy oordeel dat dit ' $n$ sterk argument kan wees, maar net waar kan wees indien die embrio's 'n vroeëre fase is van wat mense is. Hy wys op verskillende biologiese realiteite insake selverdeling en selvereniging, splitsing van embrio's, eenwording van embrio's en skepping van nuwe embrio's. Hierdie realiteite noop hom om te sê dat nóg die sel van die embrio, nóg die embrio identies is aan die volwasse mens wat daaruit ontwikkel. "They are different individuals that succeed one another." (Marquis, 2007:65.) Daarom beskou hy hierdie argument nie as geldig nie.

Sy gevolgtrekking is dat geen afleiding uit die morele beginselteorie oortuigend is nie. In die lig hiervan vra Marquis (2007:56) die vraag: "Why should the moral-principle objection be allowed to trump the promise of embryonic stem cell research when that objection seems 
to have implausible implications and the underpinnings of that object are suspect?"

\section{Hoe die etiek van stamselnavorsing verskil van die etiek van aborsie - Harman}

Harman, 'n filosoof van Princeton, volg 'n ander argumentasielyn om kritiek van sommige etici teen stamselnavorsing af te wys. Sy handel met die standpunt dat die argumente teen aborsie en embrionale stamselnavorsing eintlik maar op dieselfde neerkom (Harman, 2007:68). Sy beredeneer die saak vanuit die etici se veronderstelling dat die fetus (in die geval van aborsie) en die embrio (in die geval van embrionale stamselnavorsing) dieselfde morele status het. In haar beoordeling van hierdie siening onderskei sy tussen die skepping van embrio's vir die doeleindes van navorsing en die gebruik van embrio's wat oortollig is in fertiliteitsklinieke. Volgens die veronderstelling dat sowel die fetus as die embrio morele status het, moet die etikus dan eintlik aborsie sowel as die gebruik van die oortollige embrio's in fertiliteitsklinieke as toelaatbaar beskou - al sou iemand ook kan oordeel dat hulle morele status het.

Aborsie en in vitrobevrugting moet as aanvaarbaar beskou word omdat meer as die fetus en die embrio op die spel is, naamlik die keuse van die moeder in die geval van aborsie, en die egpaar wat 'n kind kan ontvang in die geval van in vitrobevrugting. Op die aborsieargument gaan sy nie verder in nie en haar beredenering is vaag. In teenstelling hiermee sê sy die volgende ten opsigte van die skepping van embrio's vir doeleindes van die produksie van stamselle: "I argue that if a researcher creates an embryo and then destroys the embryo to make stem cells, the researcher has significantly harmed the embryo." (Harman, 2007:71.) Embrionale stamselnavorsing is egter oneties, nie omdat die embrio's vernietig word nie, maar omdat hulle geskep word sonder enige toekomstige bestaansmoontlikheid. Die daad van produksie is immoreel en nie die vernietiging daarvan nie. Dit is dus makliker om aborsie te regverdig indien die skepping van embrio's bloot is om daaruit stamselle te verkry. Hierdie argument moet geld wanneer veronderstel word dat die fetus en die embrio volledige morele status het.

Sy kom tot die gevolgtrekking dat 'n embrio alleen morele status kan hê indien dit in die uterus ingeplant word en 'n toekoms kan hê waarin dit 'n voortdurende bewussyn kan hê. Hoewel sy, anders as die skrywers wat hierbo behandel is, tog 'n mate van morele status aan die embrio toeken, val sy egter ook terug op die Kantiaanse filo- 
sofie wat menswaardigheid koppel aan bewuste ervaring wat in die mens se rasionele vermoëns gefundeer is. Daarom is sy ten gunste van aborsie op aanvraag en embrionale stamselnavorsing.

\section{Die respek vir menslike embrio's in stamselnavorsing: op soek na harmonie - Alvarez Manninen}

Alvares Manninen skryf vanuit 'n mediese etiese perspektief en bevraagteken veral die Bush-kompromis. Sy poog verder om die kritiese standpunte van die filosoof Callahan en die teoloog Meilaender te weerlê. Hulle beweer dat die vernietiging van embrio's noodwendig beteken dat die navorser geen respek vir hulle toon nie. Sy behandel nie die skepping van embrio's vir die uitsluitlike gebruik van stamselnavorsing nie, omdat sy oordeel dat die vraagstuk van die vernietiging van duisende embrio's in fertiliteitsklinieke eers eties beoordeel moet word. In hierdie verband sê sy:

I will argue here that properly respecting human embryo's at the blastocyst stage of development, on the one hand, and destroying them for stem cell research, on the other, are not mutually exclusive. (Alvarez Manninen, 2007:88.)

Drie uitgangspunte in die betoog van Alvares Manninen is opmerklik. Eerstens gaan sy in haar siening van die waarde van die embrio ook uit van die Kantiaanse mensbeskouing. Die mens kan alleen mens wees wanneer daar sprake is van 'n funksionerende rasionele kapasiteit. Menswaardigheid rus in die rasionaliteit van die mens. Sonder rasionaliteit is die mens nie meer as die dier nie, en in hierdie verband verwys sy ook na die regverdiging van eutanasie op mense wie se brein nie meer funksioneer nie. As nie-rasionele organisme kan die embrio nie enige lyde of vreugde ervaar nie. Tweedens benader sy die etiek van stamselnavorsing vanuit 'n gesindheidsetiek wat beteken dat ' $n$ handeling geregverdig kan word deur die gesindheid waarmee die handeling uitgevoer word. Sy sluit dan aan by Lebacqs en sê: "respect or disrespect lies not alone in what acts are done, but in the attitude accompanying those acts" (Alvares Manninen, 2007:93). By gewone moord is daar 'n gesindheid van haat en dit is glad nie die geval by die vernietiging van die embrio vir stamselnavorsing nie. Die bedoeling van stamselnavorsing is immers om lewens te red en siek mense se lewenskwaliteit te beskerm.

Derdens handhaaf sy ook 'n konsekwensialistiese teorie van etiese handeling. Die uiteinde van stamselnavorsing is goed. Embrio's word vernietig ten gunste van groot mediese deurbrake en die gene- 
sing van siektes. Hierdie drie argumente van haar betoog bring haar by die konklusie dat die gebruik van embrio's vir stamselnavorsing juis beteken dat hulle as waardevol gerespekteer word. Alvares Manninen se betoog bring veral een saak in die etiese debat oor stamselnavorsing na vore, naamlik die rol wat 'n gesindheidsetiek hierin moet speel.

\section{Die moontlikheid van embrioherstel na stamsel- onttrekking - Devolder en Ward}

Devolder en Ward (2007:105) bespreek die standpunt dat embrio's herstel kan word en nie vernietig hoef te word na stamselonttrekking nie. Embrio's kan in stamselnavorsing gebruik word sonder om dit te vernietig. Die behoud van sodanige embrio's sal, volgens die voorstanders van hierdie standpunt, die angel uit die etiese besware teen die verwydering van stamselle haal, veral die besware vanuit die Joods-Christelike tradisie. Hulle bespreek die biologiese moontlikhede in hierdie verband en sê dan dat sekere ingrepe, soos byvoorbeeld partenogenese, kan meebring dat die embrio steeds "gered" kan word. Hoewel die oorspronklike struktuur van die embrio vernietig word, word die potensiaal om in 'n persoon te ontwikkel nie vernietig nie, omdat die oorspronklike embrio herstel kan word deur die gebruikmaking van sy eie selle (Devolder \& Ward, 2007:112).

Twee vrae inhibeer hierdie siening egter, naamlik hoe die embrio gedefinieer word en wanneer die embrio dan dood sou wees. Daar is volgens hulle verskillende antwoorde op hierdie vrae binne die biologie en die bio-etiek.

New techniques and new possibilities to manipulate, constitute, and reconstitute its cells have complicated the issue of what is the difference between an embryo, HESC's, and other embryolike entities and what constitutes their value. That early embryo's can be assembled, disassembled and reassembled makes them ontologically different from later stages of human development, which are less ambiguous. (Devolder \& Ward, 2007:118.)

Hulle kom tot die gevolgtrekking dat die argument dat embrio's herstel kan word en nie vernietig hoef te word nie, meer probleme skep as wat dit antwoorde bied ten opsigte van die vernietiging van embrio's as argument teen embrionale stamselnavorsing. Self kies hulle ook vir 'n konsekwensialistiese etiese teorie en bepleit die voortgang en befondsing van stamselnavorsing. 


\section{Die morele status van stamselle - Sagan en Singer}

Sagan en Singer (2007:139) argumenteer dat alle menslike entiteite, wat ook die embrio insluit, by die begin van lewe geen morele status het nie en dat die gebruik daarvan vir navorsingsdoeleindes, geregverdig is. Hulle grond hulle argument op die stelling dat indien die embrio as potensiële menswees gesien word, dieselfde gesê kan word van 'n enkele stamsel, omdat 'n mens ook uit 'n enkele stamsel kan ontwikkel. Hulle betoog soos volg:

- 'n Sel kan van 'n enkele embrio getrek word, sonder dat die embrio vernietig hoef te word. Sowel die embrio as die sellyn kan dan verder ontwikkel.

- 'n Sel kan van 'n sterwende embrio getrek word wat in elk geval nie die potensiaal van voortbestaan het nie.

- Defektiewe embrio's kan geskep word en daaruit kan stamselle getrek word.

- Deur partenogenese kan 'n eiersel sonder 'n spermsel ontwikkel en 'n sel kan daaruit verwyder word.

Waarom dan nie van hierdie prosesse gebruik maak nie? 'n Ontginning van hierdie moontlikhede vind hulle onnodig, want dit is duur en moeilik uitvoerbaar. Hierdie tegnieke, wat wel moontlik is, dui volgens hulle daarop dat die bewering dat die embrio mens-in-wording is en morele status behoort te geniet nie op vaste grond staan nie. Omdat ' $\mathrm{n}$ sel om voor die hand liggende redes nie morele status kan geniet nie, moet dus dieselfde van die embrio gesê word.

Verder betoog hulle dat meer selle vernietig word as die totaal van menselewens wat verlore gaan in oorloë, etniese suiwering en natuurrampe. Miljoene embrio's word in fertiliteitsklinieke vernietig en ander sterf 'n natuurlike dood. Alles dui daarop dat nie soveel van die morele status van die embrio gemaak behoort te word nie. Hulle vraag is dus of die vernietiging van die embrio vir die bio-etiek werklik so 'n kernsaak behoort te wees (Sagan \& Singer, 2007:124). Gesien in die lig van die feit dat embrionale stamselnavorsing onbetwiste voordele vir die mens inbring en die feit dat bevrugting nie die enigste oorsprong van menslike bestaan is nie, behoort sodanige navorsing toegelaat te word. Sagan en Singer bied ' $n$ nuwe en interessante perspektief wat dieper vrae stel aan die uitgangspunt dat die embrio menswaardig is omdat dit gesien moet word as mens-in-ontwikkeling. 


\section{Die verkoop van oösiete - Gruen}

Gruen (2007:145) bespreek die moontlikheid dat oösiete (vroulike eierselle) verkry kan word deur handel daarin toe te laat. Stamselnavorsing benodig baie oösiete - in die navorsingsfase asook in die terapeutiese fase van die werk. Honderde oösiete word vir een seloorplanting benodig. Tekorte van oösiete ontstaan dikwels en benadeel die werk van stamselnavorsing. Hoe moet hierdie oösiete bekom word op 'n manier wat eties aanvaarbaar sal wees? Volgens haar is daar ses maniere waarop oösiete bekom kan word (Gruen, 2007:146).

- Addisionele oösiete kan verkry word by vroue wat in vitrobevrugting ondergaan.

- Vroue kan dit vrywillig verskaf vir die doeleindes van stamselnavorsing.

- Oösiete kan verkry word uit uterektomies.

- Fetale uterusse kan hiervoor aangewend word na aborsies van die fetusse.

- Oösiete van diere kan gebruik word.

- Dit kan van stamselle verkry word.

Haar oordeel oor hierdie moontlikhede is dat die gebruik van fetale uterusse aborsies vir hierdie doel mag vermeerder en dit bemoeilik die aborsiedebat. Die gebruik van eierselle van diere is ook problematies, omdat dit die grens tussen die mens as rasionele wese en die dier oorskry. (Hieroor word in die volgende afdeling meer gesê.) Sy pleit vir die vrywillige skenking van oösiete en die gebruik daarvan in die in vitroproses. Hoewel die skenking van oösiete by vroue newe-effekte tot gevolg het wat van 'n ernstige aard is en kort- en langtermyn risiko's inhou, hoef dit nie die moontlikhede wat hierdie twee bronne bied, nietig te maak nie. Die einddoel is belangriker as die moontlike skade.

Ten opsigte van die vrywillige skenking en verkoop van oösiete, wys sy op die vorige president van die VSA se mening dat toelating van die gebruik van hierdie bronne tot die dehumanisering van vroue sal lei. Vir 'n waarskuwing teen die dehumanisering van vroue toon sy begrip, maar is oortuig dat die skenking of verkoop van oösiete deur vroue nie daartoe hoef te lei nie. Die kommersialisering van sodanige aanwending van die bronne kan slegs bevraagteken word indien daar ' $n$ derde party bykom wat finansiële voordeel uit die sken- 
kings trek. Sy maak in haar reaksie op die standpunt van Bush baie gebruik van die argument van 'n dubbele negatief. Sy verwys na verskeie ander wyses waarop vroue, volgens haar, op dieselfde wyse aangewend word, byvoorbeeld in prostitusie. Die toelating van een negatiewe praktyk regverdig dus 'n ander negatiewe praktyk. Hierdie etiese teorie, wat eintlik net ter sprake behoort te kom in bewese morele konflikte, vorm die grondslag van haar argumentasie ten gunste van vrywillige verskaffing of verkoop van oösiete deur vroulike skenkers. Sy kom egter tot die konklusie dat sodanige praktyk goed gereguleer behoort te word (Gruen, 2007:163). Haar beredenering van hierdie aspek van stamselnavorsing toon aan hoe belangrik die etiese diskoers oor stamselnavorsing geword het en lig weer die hoofsaak uit, te wete, wat menslike lewe is en hoe belangrik dit is

\section{Mens-dier chimeras: menswaardigheid, morele status en vooroordeel ten opsigte van spesies - DeGrazia}

Mens-dier chimeras is wesens wat ontstaan wanneer menslike selle in diere ingeplant word of andersom. Menslike en dierlike stamselle kan suksesvol in mekaar se liggame funksioneer. Dierlike selle het by die mens genesing bewerk en vice versa. DeGrazia (2007:169) onderskei tussen "humans" en "non-human animals". Hierdie prosedure is ' $n$ onderdeel van moderne stamselnavorsing wat bedoel is om vas te stel wat die stamselle se ontwikkelingspotensiaal is. In sy bydrae bespreek DeGrazia die etiese argumente wat teen hierdie prosedures gevoer word, veral die argument wat betrekking het op menswaardigheid, wat uitgaan van die standpunt dat mense groter intrinsieke morele status het as diere. Hy beperk hom tot die eksperimente wat met groot ape en knaagdiere soos muise en rotte gedoen word.

Hy begin sy betoog deur te noem dat die stelling dat mense groter morele status as diere het uit die pre-Darwinistiese wêreldbeskouing dateer toe die mens en dier as twee onverwante kreature beskou is. Met die opkoms van die evolusieteorie en die diere-etiek is daardie tyd egter verby. As voorbeeld verwys hy na homo floresiensis wat ongeveer 13000 jaar gelede bestaan het. Hierdie spesie was redelik ontwikkeld, hoewel nie soveel as homo sapiens nie. Hulle vermoëns kan vergelyk word met 'n hedendaagse kind. Maar sou dit hulle morele status verlaag? DeGrazia (2007:173) is oortuig dat dit nie die geval is nie en daarom kan dit ook nie die geval wees met die spesies wat tot die homo-genepoel behoort nie. Dit kan ook nie die geval wees met enige ander spesie nie, want wat gee aan een 
spesie in die evolusionêre patroon groter morele waarde as aan 'n ander?

Daar word verskeie argumente aangevoer om die verskil in morele status te verdedig, soos die Kantiaanse argument dat homo sapiens 'n rasionele wese is, of dat mens en dier se belange in die lewe verskillend is. Wanneer tree rasionaliteit en die verskil in lewensbelang egter in die biologiese evolusie in?

Hy voer sy argument verder deur 'n bespreking van die konsep persoonskap (personhood). Persoonskap strek verder as homo sapiens en dit verwys na die soort wese met bepaalde psigologiese trekke en vaardighede. Hierby moet wesens ingereken word "with complex forms of consciousness, such as self-awareness over time, socialbility, and rationality" (DeGrazia, 2007:178). Groot ape en ander aapspesies voldoen hieraan. Hulle het selfs 'n sekere mate van morele bewustheid. Hy noem hulle daarom "borderline persons" wat as sodanig persoonstatus behoort te geniet ${ }^{4}$ en daarom ook morele status het. By ander dierespesies ontbreek die persoonskap en kan geoordeel word dat hulle morele status nie op dieselfde vlak as die homo spesies lê nie, hoewel hulle tog 'n mate van morele status behoort te geniet vanweë bepaalde eienskappe soos gevoel en groepsidentiteit.

Die implikasies van hierdie onderskeidings vir die skepping van chimeras is volgens DeGrazia (2007:184) die volgende:

- Die aapspesies moet nie aangewend word vir die skepping van chimeras nie, want dit skend hulle morele status. Voorts word hulle belange dan ondergeskik gestel aan die voordeel vir mense. DeGrazia (2007:183) oordeel dat sulke navorsing verbied behoort te word.

- By die gebruik van knaagdiere kan anders geoordeel word. Hulle morele status is nie gelyk aan dié van die groot aapspesies nie gelukkige uitdrukking is, omdat dit juis die mens "verontpersoonlik". 'n Mens dink aan ander mense as mense met bepaalde kenmerke soos 'n naam, 'n professie en 'n bewoner van 'n bepaalde plek en nie as identiteitslose voorwerpe nie. Persoonskap (of die gebrek daaraan) kan daarom nie die fetus kwalifiseer of diskwalifiseer nie. Die gebruik van hierdie terminologie is volgens hom 'n bewys van die gebrek van die hedendaagse mediese professie se gebrek aan 'n morele filosofie en in hierdie opsig sluit hy aan by Ramsey. 
en gesien vanuit 'n konsekwensialistiese etiese teorie kan die skep van chimeras in hierdie geval moreel aanvaarbaar wees.

Hierdie debat onderstreep ook die feit dat die bio-etiek, veral die standpunte wat vanuit die post-Darwinistiese paradigma beredeneer word soos wat by DeGrazia die geval is, nog op soek is na 'n duidelike definiëring en fundering van menswaardigheid en die implikasies hiervan vir die onderskeiding tussen mens en dier. Vervolgens word gelet op Tännsjö (2007:188) se betoog oor die gepolariseerde politieke beleide oor stamselnavorsing vanuit 'n liberale demokratiese perspektief.

\section{Waarom kompromieë nie moontlik is nie - Tännsjö}

Tännsjö (2007:188) vra die vraag of stamselnavorsing in 'n liberale demokrasie kan voortgaan sonder om die etiese besware van 'n groot deel van die gemeenskap in ag te neem. Volgens hom kan die etiese argumente in hierdie verband in drie groepe saamgevat word.

- Die utilitaristiese teorie: Hierdie teorie, wat reeds vroeër in hierdie artikel gedefinieer is, keur die skepping en vernietiging van embrio's vir stamselnavorsing goed, omdat dit groot voordele vir die mens inhou en geluk sal bring aan mense wat ernstig siek is. Stamselnavorsing met embrio's sal die wêreld 'n beter plek maak.

- Die morele regteteorie: Hierdie teorie beteken, volgens Tännsjö, dat alle individuele persone regte het, en 'n belangrike reg is die reg van privaatheid van die individu. Die individu moet dus besluit wat reg en verkeerd is en die skepping en vernietiging van die embrio is dus uitsluitlik 'n saak van die agent wat daarby teenwoordig is. Voorts kan slegs 'n persoon morele regte hê en 'n embrio is nie 'n persoon nie. Die embrio het dus geen regte nie en kan nie aanspraak maak op die reg om lewe nie.

- Die "heiligheid-van-die-lewe"-teorie: Hierdie teorie is deontologies en beskou die skepping en vernietiging van embrio's as onaanvaarbaar in alle omstandighede.

Tännsjö (2007:199) oordeel dat hierdie teorieë nie versoen kan word nie en mekaar prinsipieel uitsluit. Geen kompromieë is moontlik nie. Liberaalgesindes kan egter een toegewing maak, en dit is dat mense se intellektuele vryheid in enige besluitneming in ag geneem behoort te word. Die owerheid moet die epistemiese vraag oophou en neutraal staan teenoor al hierdie etiese teorieë sodat individue in 'n oop debat mekaar kan oortuig van hulle onderskeie standpunte. 


\section{Konklusie}

Hierdie artikels bied op goed beredeneerde wyse die belangrikste standpunte aan wat tans in die bio-etiek ten opsigte van embrionale stamselnavorsing aan die orde is. Hierdie standpunte kan by wyse van kernvrae soos volg saamgevat word.

- Wat is die morele status van die embrio? Hierdie vraag is die kernvraag waarrondom die debat sentreer. Devolder, Harris, Macmahan en Tännsjö is oortuig dat die embrio nie 'n mens is nie en nie morele status behoort te geniet nie. Marquis oordeel dat die embrio wel mens is en dus morele status behoort te geniet, maar dat hierdie feit nie embrionale stamselnavorsing behoort te inhibeer nie.

- Is die embrio 'n potensiële mens? Dieselfde skrywers asook Marquis sê verder dat die embrio nie 'n potensiële mens is nie, want dan kan dieselfde van 'n eiersel en enige ander menslike sel gesê word. Die embrio is slegs 'n stadium in die ontwikkeling van die mens en kan dus vernietig word ten gunste van navorsing.

- Het die embrio regte? Sagan en Singer koppel morele regte aan rasionaliteit (Kantiaanse standpunt). Hulle oordeel dat die feit dat die embrio nie 'n rasionele komponent het nie, beteken dat die embrio geen regte kan geniet nie. Harman sê egter dat die embrio wel waarde kan hê, maar slegs indien dit in die uterus ingeplant is.

- Is die skep van chimeras en die verkoop van oösiete eties geregverdig? Oor oösiete oordeel Gruen dat die praktyk op grond van 'n konsekwensialistiese teorie geregverdig kan word met die voorwaarde dat die owerhede die praktyk goed reguleer. DeGrazia regverdig op grond van dieselfde teorie die skep van chimeras waar knaagdiere gebruik word, maar nie waar die groot aapsoorte ter sprake kom nie, omdat hulle ook as persone gereken moet word.

- Ten slotte kan ook gevra word: In hoe 'n mate kan 'n konsekwensialistiese teorie, 'n utilitaristiese teorie, 'n gesindheidsteorie of die dubbele-negatief as argument in hierdie debat gebruik word? Is stamselnavorsing werklik 'n morele konflik wat die gebruik van die teorieë wat in 'n nood-etiek wenslik is, regverdig? (vgl. Vorster, 2004:109).

Van kernbelang in hierdie debat is egter die vraag na die morele status (menswaardigheid) van die menslike embrio. Is die embrio slegs 
'n organisme of 'n losstaande fase van menslike ontwikkeling of 'n potensiële mens of 'n ontwikkelende mens? Hierop moet die deontologiese Christelike etiek antwoord en ek beoog om in 'n volgende navorsingsartikel 'n voorlopige standpunt oor die menswaardigheid van die menslike embrio te beredeneer. Hopelik sal die ander vrae wat hierbo genoem is later aan die orde kom.

\section{Geraadpleegde bronne}

ALVAREZ MANNINEN, B. 2007. Respecting human embryo's within stem cell research: seeking harmony. (In Gruen, L., Grabel, L. \& Singer, P. Stem cell research: the ethical issues. Oxford: Blackwell. p. 86-104.)

BROWN, M.T. 2007. The potential of the human embryo. Journal of medicine and philosophy, 32:585-618.

BUSH, G.W. 2001. Remarks on stem cell research. http://www.whitehouse.gov/ news/releases/2001/08/20010809-2.html Date of access: 1 Aug. 2009.

CAMPBELL, A. 2005. Ethos and economics: examining the rationale underlying stem cell research and cloning research policies in the United States, Germany and Japan. American journal of law \& medicine, 31:47-86.

CAVE, E. 2004. The mother of all crimes: human rights, criminalization and the child born alive. Leeds: Ashgate.

CHILDRESS, J.F. 2001. Christian ethics, medicine and genetics. (In Gill, R., ed. The Cambridge companion to Christian ethics. Cambridge: Cambridge University Press. p. 261-276.)

$\mathrm{CHU}, \mathrm{G}$. 2003. Embryonic stemcell research and the moral status of embryos. Internal medicine journal, 33:530-531.

DEGRAZIA, D. 2007. Human-animal chimeras: human dignity, moral status and species prejudice. (In Gruen, L., Grabel, L. \& Singer, P. Stem cell research: the ethical issues. Oxford: Blackwell. p. 168-187.)

DEVOLDER, K. \& HARRIS, J. 2007. The ambiguity of the embryo: ethical consistency in the human embryonic stem cell debate. (In Gruen, L., Grabel, L. \& Singer, P. Stem cell research: the ethical issues. Oxford: Blackwell. p. 16-31.)

DEVOLDER, K. \& WARD, C.M. 2007 Rescuing human embryonic stem cell research: the possibility of embryo reconstitution after stem cell derivation. (In Gruen, L., Grabel, L. \& Singer, P. Stem cell research: the ethical issues. Oxford: Blackwell. p. 105-123.)

GIBSON, S. 2007. Uses of respect and uses of the human embryo. Bioethics, 21(7):370-378.

GRUEN, L. 2007. Oocytes for sale? (In Gruen, L., Grabel, L. \& Singer, P. Stem cell research: the ethical issues. Oxford: Blackwell. p. 145-167.)

GRUEN, L. \& GRABEL, L. 2007. Introduction: ethics and stem cell research. (In Gruen, L., Grabel, L. \& Singer, P. Stem cell research: the ethical issues. Oxford: Blackwell. p. 1-15.)

GRUEN, L., GRABEL, L. \& SINGER, P. 2007. Stem cell research: the ethical issues. Oxford: Blackwell.

GUSTAFSON, J.M. 1981. Ethics from a theocentric perspective. Vol. 1: Theology and ethics. Chicago: University of Chicago Press. 
HARMAN, E. 2007. How is the ethics of stem cell research different from the ethics of abortion? (In Gruen, L., Grabel, L. \& Singer, P. Stem cell research: the ethical issues. Oxford: Blackwell. p. 67-85.)

HAUERWAS, S. 2001. The Hauerwas reader. Durham: Duke University Press.

HOLM, S. 2002. Going to the roots of the stem cell controversy. Bioethics, 16(6):494-507.

IOANNES PAULUS P.P. II. 1995. Evangelicum vitae, encyclical letter. http://www.ukessays.com/essays/human-rights/abortion.php Date of access: 1 Oct. 2009.

KALB, C. 2009. A new stem cell era. http//www.newsweek.com/id/188454 Date of access: 20 Jul. 2009.

LITE, J. 2009. Obama ends embryonic stem cell research ban. http://www. scientificamerican.com/blog/60-second/post.cfm?id=obama-ends-em Date of access: 20 Jul. 2009.

MACMAHAN, J. 2007. The killing of embryo's for stem cell research. (In Gruen, L., Grabel, L. \& Singer, P. Stem cell research: the ethical issues. Oxford: Blackwell. p. 32-50.)

MARQUIS, D. 2007. The moral-principle objection to human embryonic stem cell research. (In Gruen, L., Grabel, L. \& Singer, P. Stem cell research: the ethical issues. Oxford: Blackwell. p. 51-66.)

OBAMA, B. 2009. Obama ends funding ban for stem cell research. http://www. youtube.com/watch?v=63Uqp9VcCq4 Date of access: 20 Jul. 2009.

ODERBERG, D.S. 2005. Human embryonic stem cell research: what is wrong with it? The human life review: 21-33, Fall.

POPE, S.J. 2007. Human evolution and Christian ethics. Cambridge: Cambridge University Press.

RHEEDER, A.L. 2008a. Stamselnavorsing en -terapie: 'n oorsig oor die uitvoerbaarheid daarvan met meegaande etiese implikasie. In die Skriflig, 42(3):469-498.

RHEEDER, A.L. 2008b. Stamselnavorsing en terapie: 'n voorlopige teologiesetiese beoordeling. In die Skriflig, 42(4):709-734.

ROBERTSON, J.A., KAHN, J.P. \& WAGNER, J.J. 2002. Conception to obtain haematopoietic stem cells. Hastings center report, 32(3)34-40.

ROBINSON, J. 2002. Crossing the ethical chasm: embryo status and moral complicity. The American journal of bioethics, 2(1):33-34.

SAGAN, A. \& SINGER, P. 2007. The moral status of stem cells. (In Gruen, L., Grabel, L. \& Singer, P. Stem cell research: the ethical issues. Oxford: Blackwell. p. 124-144.)

SCHUKLENK, U. \& LOTT, J. 2002. Ethics politics and stem cell research in South Africa. South African medical journal, 92(10):782-786.

STRETTON, D. 2000. The argument from intrinsic value: a critique. Bioethics, 14(3):228-239.

TÄNNSJÖ, T. 2007. Why no compromise is possible. (In Gruen, L., Grabel, L. \& SINGER, P. Stem cell research: the ethical issues. Oxford: Blackwell. p. 188-201.)

VOGEL, B., ed. 2007. At the centre: human dignity - Christian responsibility as a basis for the practice of politics: Christian ethics as a guide. Berlin: Konrad Adenhauer Stiftung.

VORSTER, J.M. 2004. Ethical perspectives on human rights. Potchefstroom: Potchefstroom Theological Publications. 


\section{Kernbegrippe:}

aborsie

embrionale stamselnavorsing

morele status

\section{Key concepts:}

abortion

embryonic stem cell research

moral status 